\title{
УДК 373.542:811.161.2
}

Кучерук Оксана Анатоліївна

доктор педагогічних наук, професор, професор кафедри світової літератури та методик викладання філологічних дисциплін

Житомирський державний університет імені I. Франка, м. Житомир, Україна

ORCID 0000-0002-7040-986X

okucherukl@ukr.net

\section{ФОРМУВАННЯ ЛЕКСИЧНОЇ КОМПЕТЕНТНОСТІ УЧНІВ ЗАСОБАМИ КОМП’ЮТЕРНИХ ІГОР У НАВЧАННІ УКРАЇНСЬКОЇ МОВИ}

\begin{abstract}
Анотація. У статті розглянуто проблему формування лексичної компетентності учнів молодшого підліткового віку з використанням комп'ютерних ігор у процесі навчання української мови, запропоновано шляхи її розв'язання і відповідні методичні рекомендації. Обгрунтовано актуальність створення й використання комп'ютерних ігор 3 метою підвищення якісного рівня українськомовної освіти. Уточнено сутність понять «лексична компетентність», «навчально-комп'ютерна гра». На основі аналізу наукових праць, синтезу навчально-методичних ідей, узагальнення власного досвіду педагогічної роботи визначено умови ефективного використання навчально-комп'ютерних ігор у межах українськомовної освіти. Установлено, що інтеграція комп'ютерних ігор у традиційну систему навчання української мови сприяє забезпеченню внутрішньої мотивації до навчання, активізації пізнавальної діяльності учнів, формуванню загальних і предметних компетентностей. Наголошено, що ефективність навчальних комп'ютерних ігор у мовній підготовці учнів залежить від рівня професійної освіти, ІКТ-компетентності й лінгвометодичної майстерності вчителя-словесника. Описано навчальний потенціал інтерактивного навчально-ігрового комплексу, що полягає в стимулюванні інтересу до навчання української мови й створює можливості для формування лексичної компетентності на засадах електронної лінгводидактики.
\end{abstract}

Ключові слова: лексична компетентність; навчально-комп'ютерна гра; електронна лінгводидактика; інтерактивний навчально-ігровий комплекс.

\section{1. ВСТУП}

Постановка проблеми. Особливість сучасного розвитку шкільної українськомовної освіти пов'язана зі спрямуванням іiі на формування загальних i предметної компетентностей мовної особистості учнів. Базовим складником предметної компетентності з української мови є лексична компетентність, від якої значною мірою залежить багатство й різноманітність мовлення особи. Однак, як зазначають дослідники, лексична підготовка носіїв української мови потребує вдосконалення. Для того щоб формування лексичної компетентності відбувалося на якісно новому рівні, необхідно методично доцільно використовувати електронні освітні ресурси. Один із таких ресурсів - навчальні комп'ютерні ігри. Розроблені на предметному матеріалі, вони допомагають підвищити інтерес до навчання української мови й забезпечити орієнтування на особистісне зростання учнів шляхом оновлення освітнього середовища. Натомість використання вчителями інформаційнокомунікаційних технологій (IКТ) у шкільному курсі української мови переважно зводиться до того, що вчителі здебільшого показують учням комп'ютерні презентації, створюють веб-сторінки навчального характеру для самостійної роботи учнів, але комп'ютерних навчально-предметних ігор, зазвичай, не використовують, лише окремі вчителі інколи в навчанні української мови практикують комп’ютерні квести. 
Аналіз останніх досліджень і публікацій. Студіювання наукової літератури свідчить, що питання лексичної підготовки учнів засобами традиційного навчання української мови досліджують М. Вашуленко, О. Горошкіна, Т. Груба, Н. Дика, С. Караман, О. Караман, В. Новосьолова, О. Семеногта ін. У лінгвометодичних працях цих учених запропоновано варіативні механізми шкільної роботи 3 опанування лексикології на основі соціокультурного, функційно-комунікативного, дослідницького та інших підходів до навчання, оскільки зазначене питання є багатоаспектним. Один із таких підходів передбачає використання навчальних технологій 3 комп'ютерною підтримкою в системі мовної освіти. Однак аналіз відповідних наукових публікацій переконує, що можливості комп'ютерних технологій (інформаційно-пошукових, комунікаційних, ігрових та ін.) у навчанні української мови загалом та в роботі над лексикою зокрема враховуються недостатньо, а комп'ютерні навчальні ігри ще не стали об’ єктом грунтовних лінгводидактичних досліджень. Г. Корицька слушно зазначає, що на сьогодні потребують досліджень основні підходи до організації шкільної мовної освіти в умовах розвитку електронного освітнього середовища, застосування сучасних технологій оволодіння мовою, навчання української мови на засадах електронної лінгводидактики [1, с. 41]. Отже, недостатня увага у вітчизняній лінгводидактиці (та практиці навчання української мови) до використання IКТ у процесі формування компетентної мовної особистості учнів свідчить про необхідність активного науковометодичного пошуку більш дієвих шляхів розв'язання проблем українськомовної освіти, зокрема в аспекті покращання лексичної підготовки учнів засобами навчальних комп'ютерних ігор.

Мета статті. Мета дослідження - визначити теоретико-методичні умови формування лексичної компетентності молодших підлітків з використанням навчальнокомп’ютерних ігор у процесі навчання української мови. Реалізація поставленої мети передбачає розв'язання відповідних завдань: уточнити сутність понять «лексична компетентність», «навчально-комп'ютерна гра»; 3'ясувати співвідношення між лексичною компетентністю i мовленнєвим розвитком учнів; окреслити лінгводидактичні положення, які лежать в основі шкільної роботи над лексичними засобами української мови 3 використанням комп'ютерних навчальних ігор у 5-6 класах.

\section{2. МЕТОДИКА ДОСЛІДЖЕННЯ}

У методиці проведення дослідження використано різні методи наукової роботи: аналіз науково-методичних праць 3 проблемних питань формування лексичної компетентності учнів засобами навчально-комп'ютерних ігор, синтез навчальнометодичних ідей; узагальнення власного педагогічного досвіду в системі українськомовної освіти; метод опису інтерактивного навчально-ігрового комплексу; інтерпретація результатів дослідницької роботи.

\section{3. РЕЗУЛЬТАТИ ДОСЛІДЖЕННЯ}

На процес формування мовної особистості значний вплив мають індивідуальні знання лексики й уміння та досвід використання їх у мовленнєвій практиці. Тому важливим завданням шкільної українськомовної освіти $є$ вироблення в учнів лексичної компетентності, яка становить мовну основу їхнього мовленнєвого розвитку. Загальновідомо, що від володіння учнем лексичною компетентністю залежить рівень його мовленнєвої поведінки. У цьому контексті вважаємо, що особливість лексичної компетентності як особистісного складного утворення, сформованого на інтеграції 
ціннісного, пізнавального й поведінкового компонентів, зумовлюється тим, що вона дає змогу адекватно пізнавати явища дійсності й виконувати мисленнєво-мовленнєву діяльність, оскільки грунтується на вільному володінні українським словниковим багатством, усвідомленні зв'язку слова з позамовною дійсністю, культурою, побутом, традиціями, звичаями українського народу, загальнолюдськими цінностями, здатності швидко та оригінально добирати словесні асоціації для програмування й реалізації власної мовленнєвої поведінки в комунікативних ситуаціях. 3 огляду на зазначене лексична компетентність $є$ показником i засобом багатоаспектного особистісного розвитку учнів.

За В. Новосьоловою, лексична компетентність - це складник мовної компетентності, який полягає в усвідомленому й умотивованому оволодінні лексичними засобами мови й умінні користуватися ними. Дослідниця слушно зазначає, що лексична компетентність передбачає не лише наявність багатого словникового запасу, а й уміння використовувати наявні в активі лексичні елементи в процесі мовлення для вираження своєї позиції й ставлення до сказаного, здатність варіювати лексичними засобами залежно від сфери й ситуації, у яких відбувається комунікативний процес [2, с. 19].

Проблему лексичної компетентності досліджують зарубіжні науковці (V. Evans, D. Marconi та ін.). Зокрема, Д. Веласко розглядає лексичну компетентність як уміння використовувати слова у відповідних і ефективних способах у вербальній взаємодії, як компонент комунікативної компетентності (D. Velasco, 2007) [3, c. 166].

На основі вивчення порушеної проблеми можна стверджувати, що формування лексичної компетентності учнів у процесі навчання української мови - це складний процес створення необхідних умов для цілеспрямованого збагачення словникового запасу, удосконалення пізнавально-мовленнєвого досвіду учнів; опанування ними лексичних норм сучасної української мови в аспекті семантики, творення, функціонування слів; вироблення навичок ідентифікації лексичних одиниць у навчальному тексті, розвитку лексичних умінь, здатностей швидко й оригінально добирати вербальні асоціації для мовленнєвого спілкування; стимулювання емоційноціннісного ставлення до української мови й мовлення на основі розвиненого в учнів чуття слова.

Для нас важливою $є$ думка Д. Равена про те, що для розвитку в учнів компетентностей високого рівня необхідно, аби вони мали змогу застосовувати компетентності в процесі виконання цікавої для них діяльності. Щоб організувати процес навчання, орієнтований на розвиток компетентностей, учителі мають пропонувати такі завдання, які створюють в учня мотивацію й базуються на розвинутих у нього компетентностях [4, с. 65, с. 86]. Природну особистісно значущу цікавість в учнів молодшого підліткового віку викликає навчально-ігрова діяльність. Відповідно до психофізіологічних особливостей сучасних учнів молодшого підліткового віку (розсіяна увага, непосидючість, природна цікавість, кліпове мислення та ін.) ефективними засобами навчальної роботи над лексикою $є$ ігри-змагання, ігри-конкурси, ігри-вікторини, ігри-пазли, ігри-подорожі (квести). Важливо врахувати, що молодші підлітки швидко втомлюються, тому бажано часто урізноманітнювати форми, методи, засоби навчання, зокрема й видозмінювати навчально-ігрову діяльність. Попри значну кількість наукових робіт, присвячених питанням гри, у працях учених недостатньо уваги приділено навчально-комп'ютерним іграм, відсутнє загальноприйняте визначення суті поняття «навчально-комп’ютерна гра».

На основі узагальнення науково-педагогічного досвіду навчально-комп'ютерну гру розглядаємо як метод і засіб навчання. Навчально-комп'ютерна гра, з одного боку, - це метод розвивальної взаємодії суб' єктів навчання і комп'ютера, за допомогою якого 
моделюються й імітуються навчально-предметні й життєві ситуації, розв'язання яких потребує дотримання певних правил; а з іншого, - це електронний навчальний ресурс, у якому спеціально програмується навчально-ігрова діяльність учнів. Якщо метод навчально-комп'ютерної гри становить складну структуру, то він набуває нової якості й перетворюється на ігрову технологію навчання.

Беззаперечно, у наш час розвивальний потенціал мають комп'ютерні навчальні ігри з української мови. У розробленні змісту й процедури відповідних ігор та їх використанні необхідно дотримуватися таких принципів: предметно-тематичної доцільності, природовідповідності гри з урахуванням базової предметної підготовки учнів, інтерактивності, мультимедійності, проблемності, текстоцентризму, моделювання навчально-предметних і життєвих ситуацій, внутрішньопредметних i міжпредметних зв'язків. Ефективне впровадження навчально-комп'ютерної гри в процес українськомовної освіти залежить від низки умов: мотивації учнів до навчального предмета; діалогізації навчання; рівня IКТ-компетентності учнів і вчителясловесника; рівня професійної освіти й лінгвометодичної майстерності педагога; матеріально-технічної бази (комп’ютер, проектор, інтерактивна дошка чи проекційний екран) і програмного забезпечення (електронні програми, соціальні сервіси мережних технологій Web 2.0).

У навчанні української мови навчально-комп'ютерні ігри можуть використовуватися для актуалізації асоціативно-вербальної сітки учнів, для збагачення й закріплення словникового багатства, формування лінгвокогнітивного досвіду, мовленнєвих навичок і комунікативних умінь, що, своєю чергою, забезпечує розвиток лексичної компетентності учнів. Методично доцільно побудована й реалізована гра має потужний вплив на когнітивно-комунікативне опанування мови.

Прикладом комп'ютерних ігор, придатних для формування лексичної компетентності учнів у навчанні української мови $є$ інтерактивний навчально-ігровий комплекс «Украӥнська мова в іграх», розроблений Л. Мелешко у співпраці з автором цієї статті в межах наукового проекту за допомогою програми Microsoft PowerPoint (див. $\quad$ рис. 1 ) $\mathrm{i}$ розміщений в (https://drive.google.com/open?id=1xt2ZLmseqBubhc44gRemRTBazsJZBFHg) [5].

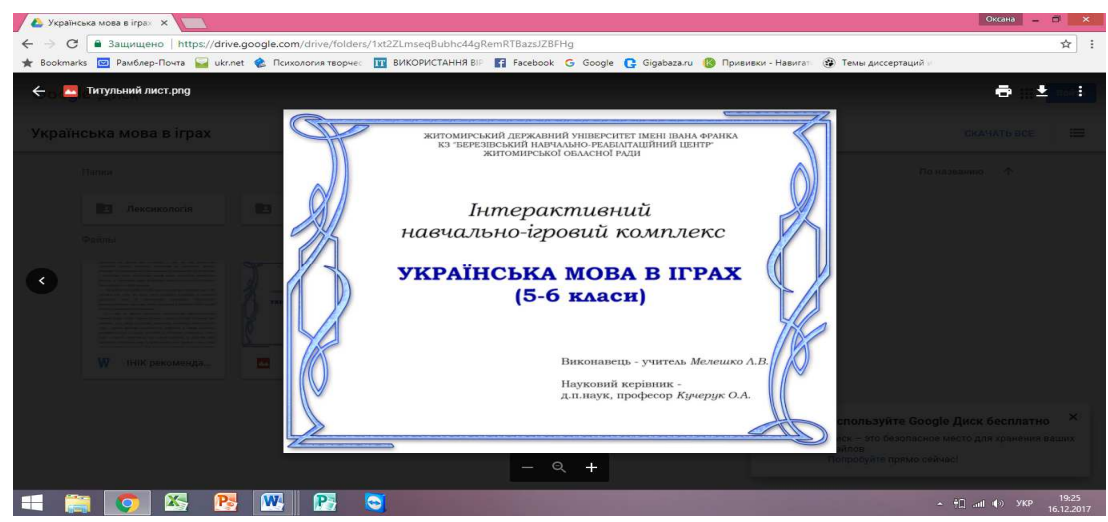

Рис. 1. Відображення титульного листа навчально-ігрового комплексу «Украӥнська мова в іграх (5-6 класи)» на дисплеї комп'ютера

Перша частина вказаного комплексу побудована на основі матеріалу 3 лексикології й відповідно передбачає формування лексичної компетентності учнів молодшого підліткового віку за такими основними напрямами роботи над лексичними засобами: 1) цілеспрямоване збагачення словникового запасу учнів i формування пізнавальної картини світу; 2) оволодіння лексикологічними знаннями; 3) засвоєння норм слововживання; 4) розвиток мовленнєвих навичок і вмінь учнів у різних жанрах 
(прохання, привітання, бесіда та ін.), удосконалення комунікативної здатності. Папка першої частини комплексу («Лексикологія») складається 3 п’яти файлів, кожен із яких містить тематичну гру (див. рис. 2).

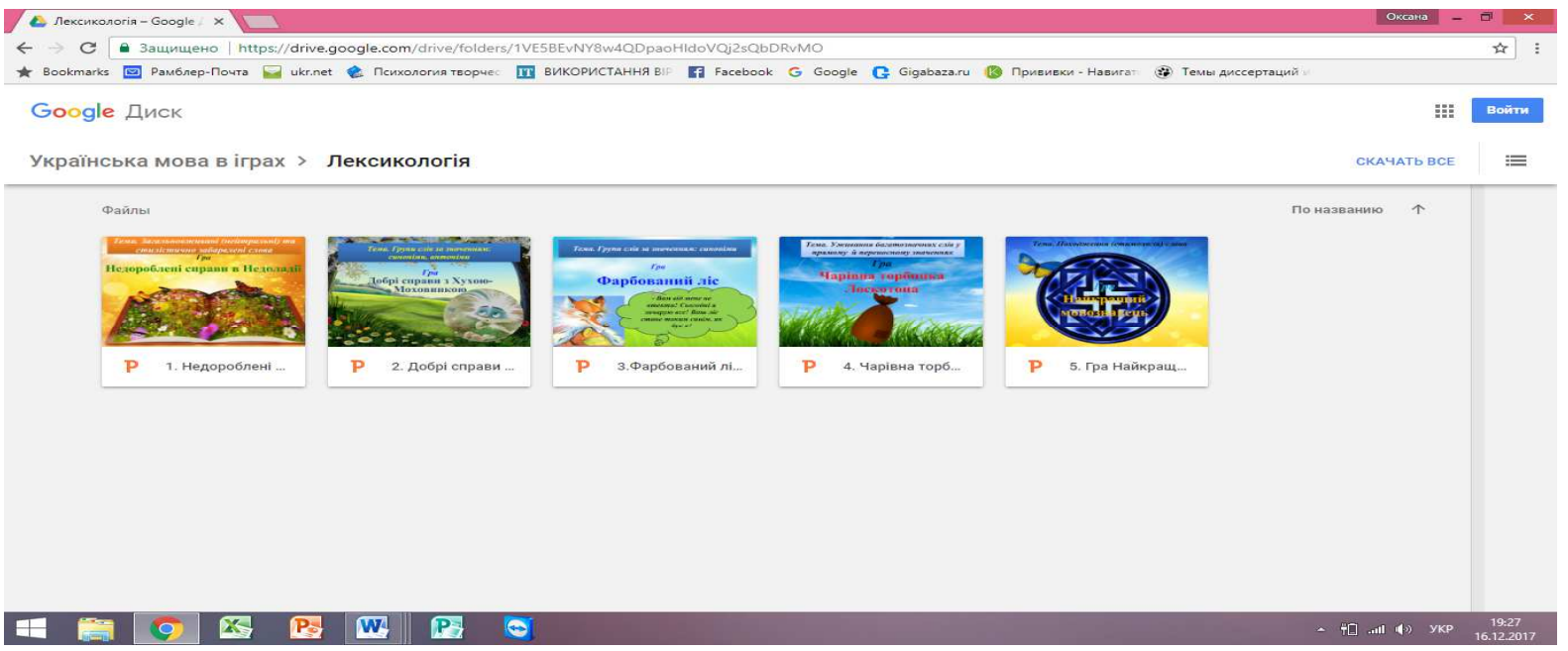

Рис. 2. Відображення титульних листів навчально-комп'ютерних ігор 3 лексикології в комплексі «Украӥнська мова в іграх (5-6 класи)» на дисплеї комп’ютера

3 огляду на зазначене можна стверджувати, що навчальні ігри першої частини комплексу об'єднані ідеєю «Грай-лексикологію вивчай!», вони містять ігровий матеріал 3 таких тем розділу «Лексикологія»: 1) «Загальновживані (нейтральні) та стилістично забарвлені слова» (гра «Недороблені справи в Недоладї»); 2) «Групи слів за значенням: антоніми» (гра «Добрі справи з Хухою-Моховинкою»); 3) «Групи слів за значенням: синоніми» (гра «Фарбований ліс»); 4) «Уживання багатозначних слів у прямому й переносному значеннях» (гра «Чарівна торбинка Лоскотона»); 5) «Походження (етимологія) слова» (гра «Найкращий мовознавець»).

Сценарій гри-квесту «Недороблені справи в Недоладї» побудований за мотивами казки Галини Малик «Незвичайні пригоди Алі в країні Недоладії», 3 якою учні знайомляться на уроках української літератури в 5 класі. Гра складається з чотирьох завдань: розкласти картки-слова відповідно до стилю мовлення; прочитати текст, визначити сферу використання, стиль, спеціальні терміни, функцію стилю тексту; написати лист-прохання, використовуючи запропоновані на слайді мовні кліше; 3 опертям на тлумачний словник пояснити значення слів гарнізон, провіант, цитадель, бастіон. Виконуючи завдання, учні мають допомогти казковим персонажам (Недобороді, Недокоролю, Недоштаньку, Недораднику) доробити справи, водночас відповідна система роботи спонукає учасників гри до пошуку нових знань, засвоєння невідомих їм слів. Успішне виконання всіх завдань допоможе учням закріпити вивчений тематичний матеріал про загальновживані та стилістично забарвлені слова, забезпечить розвиток мовленнєвої здатності, чуття слова, стилю, емпатії.

В умовах комп'ютерної гри «Добрі справи з Хухою-Моховинкою» учням пропонується робити добрі справи разом із лісовою істотою Хухою (героїнею казки «Хуха-Моховинка», автор Василь Королів-Старий), виконуючи тематичні завдання: скласти з поданих слів прислів'я, знайти слова-антоніми; «назбирати» якнайбільше синонімів до слів добрий, поганий; замінити прикметник добрий на стилістично кращий варіант; використовуючи синоніми до вказаних слів, написати лист-розповідь другу про добру справу. 
У комп'ютерній грі «Фарбований ліс» головний герой - це Лис Микита (персонаж із казки I. Франка «Фарбований Лис»), він зачаровує-зафарбовує ліс у синій колір. Щоб перемогти чари Лиса, учні мають правильно виконати завдання: розгадати кросворд «Лісові мешканці»; дібрати синоніми до слова «діброва»; прослухати вірш О. Підсухи «Ой, яка чудова українська мова!», виписати у дві колонки спільнокореневі слова й синоніми; розіграти в парах діалог на тему «Яка чудова українська мова». Гра пробуджує інтерес до цікавих фактів мови. Учасники гри вчаться розпізнавати й розуміти значення слів в аудіотексті, усному й письмовому мовленні, працювати 3 синонімами, будувати власні висловлювання.

Сценарій гри-квесту «Чарівна торбинка Лоскотона» побудований за мотивами віршованої казки В. Симоненка «Цар Плаксій та Лоскотон». Головному героєві гри дядькові Лоскотону - учні мають допомогти знайти чарівну торбинку, для цього потрібно виконати завдання від трьох доньок царя Плаксія (Плакоти, Нудоти, ВайВай): знайти пропущену літеру й відгадати слово; встановити, що об'єднує подані слова; довести, однозначним чи багатозначним є слово золотий; прочитати подану на слайді байку, виписати словосполучення зі словом золотий, пояснити їх значення; замінити в поданих словосполученнях іменник, щоб прикметник уживався в прямому значенні; скласти за поданим початком казку. Відповідна робота над словом збагачує лексичний запас учнів і розвиває в них чуття слова та образне мовлення.

Комп'ютерна гра «Найкращий мовознавець» передбачає виконання 11 тестових завдань, відповідно до яких потрібно дати відповіді, зокрема, на запитання про те, що вивчає етимологія; який український відповідник слова лауреaт; із якої мови запозичено слова базар, сарай, кавун, тютюн; у якій групі всі слова належать до власне української лексики та ін. Як супровідні в цій грі можна розглядати такі завдання: скласти сенкан зі словами власне української лексики (лелека, баритися, соняшник, мрія, багаття); написати й озвучити привітання однокласнику, який правильно виконав усі завдання гри. Гра «Найкращий мовознавець» уможливлює перевірити навчальні досягнення учнів в аспекті походження слова і водночас сприяє формуванню мовної свідомості на основі проблемного підходу та розвиткові мовлення на засадах креативності.

Окреслені комп'ютерні ігри спрямовані на формування лексичної компетентності як мовної основи мовленнєвого розвитку учнів. Характерною особливістю цих ігор є інтеграція навчально-предметної та ігрової діяльності, динамічність, наочність, аудіосупровід (додано звукові файли у слайди презентацій), наростання складності завдань, предметно-тематична різноманітність, вікова відповідність, зв'язок 3 українською літературою. Текстові матеріали й зображення для вказаного комплексу комп'ютерних ігор взято з електронних ресурсів, які розміщено у вільному доступі. Ігрові завдання комплексу збагачують учнів лексико-смисловими й лексикотематичними асоціаціями, формують знання і вміння з лексикології, підвищують увагу, розвивають мислення і мовлення, здатність доцільно володіти українським словом. Завдання вчителя-словесника під час використання наведених ігор - вчити культури гри зі словами та іншими мовними одиницями, формувати культуру мовлення, виробляти культуру ігрової діяльності й загалом виховувати культуру соціальної поведінки учнів.

\section{4. ВИСНОВКИ ТА ПЕРСПЕКТИВИ ПОДАЛЬШИХ ДОСЛІДЖЕНЬ}

Отже, 3 огляду на важливість лексичної компетентності як мовної основи мовленнєвого розвитку носія мови й недооцінювання вчителями-словесниками освітнього потенціалу ігрової діяльності та засобів ІКТ, у дослідженні визначено 
теоретико-методичні умови формування лексичної компетентності молодших підлітків з використанням навчально-комп'ютерних ігор у процесі навчання української мови.

Вивчення наукових праць дало змогу уточнити базові для цієї статті поняття, інтерпретувати співвідношення між лексичною компетентністю i мовленнєвим розвитком учнів, з'ясувати лінгводидактичні положення, які лежать в основі шкільної роботи над лексикою з використанням навчально-комп'ютерних ігор. Встановлено, що значний методичний потенціал для формування лексичної компетентності має описаний у статті інтерактивний комплекс комп'ютерних ігор для навчання української мови, оскільки містить цікаві для учнів ігрові завдання, а тому підвищує мотивацію до навчально-виховного процесу, приносить задоволення від ігрового навчання предмета, забезпечує оновлення навчально-предметного середовища, створює можливості для формування лексичної компетентності на засадах е-лінгводидактики. Розроблення й застосування навчально-комп'ютерних ігор з української мови для молодших підлітків сприяє більш ефективному розв'язанню основних завдань компетентнісно спрямованої мовної освіти порівняно з традиційними методами навчання, тому важливо розвивати й удосконалювати такі ігри.

Перспективу мають подальші дослідження організаційно-методичних аспектів навчання української мови учнів і студентів із використанням електронних освітніх ігрових ресурсів.

\title{
СПИСОК ВИКОРИСТАНИХ ДЖЕРЕЛ
}

[1] Г. Корицька, Шкільна мовна освіта в умовах розвитку електронного навчального середовищза», Elearning y теорії та практиці навчання суспільно-гуманітарних дисциилін, Івано-Франківськ, Україна: Симфонія форте, с. 40-54, 2017.

[2] В. Новосьолова, "Методи, прийоми й засоби навчання в процесі формування лексичної компетентності учнів 5-7 класів", Украӥнська мова і література в школі, №3 (113), с. 19-23, 2014.

[3] Velasco Daniel García, Lexical competence and functional discourse grammar, Бразилія: Alfa, SãoPaulo, $51 \quad$ (2): $\quad$ c.165-187, 2007.[Електронний ресурс]. Доступно: http://piwik.seer.fclar.unesp.br/alfa/article/viewFile/1442/1150.

[4] Джон Равен, Педагогическое тестирование: Проблемы, заблуждения, перспективы, Москва, Россия: Когито-Центр, 2001.

[5] Л. В. Мелешко, "Інтерактивний навчально-ігровий комплекс. Українська мова в іграх (5-6 класи) ". [Електронний ресурс]. Доступно: https://drive.google.com/open?id=1xt2ZLmseqBubhc44gRemRTBazsJZBFHg. Дата звернення: Груд. 16, 2017.

Матеріал надійчов до редакиї 22.122017 p.

\section{ФОРМИРОВАНИЕ ЛЕКСИЧЕСКОЙ КОМПЕТЕНТНОСТИ УЧЕНИКОВ СРЕДСТВАМИ КОМПЬЮТЕРНЫХ ИГР В ОБУЧЕНИИ УКРАИНСКОМУ ЯЗЫКУ}

\author{
Кучерук Оксана Анатольевна, \\ доктор педагогических наук, профессор, \\ профессор кафедры мировой литературы и методик преподавания филологических дисциплин \\ Житомирский государственный университет имени Ивана Франко, г. Житомир, Украина \\ ORCID ID 0000-0002-7040-986X \\ okucherukl@ukr.net
}

Аннотация. В статье рассмотрена проблема формирования лексической компетентности учащихся младшего подросткового возраста с использованием компьютерных игр в процессе обучения украинскому языку, предложены пути ее решения и соответствующие 
методические рекомендации. Обоснована актуальность создания и использования компьютерных игр с целью повышения качественного уровня украиноязычного образования. Уточнена сущность понятий «лексическая компетентность», «учебнокомпьютерная игра». На основе анализа научных работ, синтеза учебно-методических идей, обобщения собственного опыта педагогической работы определены условия эффективного использования учебно-компьютерных игр в украиноязычном образовании. Установлено, что интеграция компьютерных игр в традиционную систему обучения украинскому языку способствует обеспечению внутренней мотивации к обучению, активизации познавательной деятельности учащихся, формированию общих и предметных компетентностей. Акцентировано, что эффективность учебных компьютерных игр в языковой подготовке учащихся зависит от уровня профессионального образования, ИКТкомпетентности и лингвометодического мастерства учителя-словесника. Описан учебный потенциал интерактивного учебно-игрового комплекса, который состоит в стимулировании интереса к обучению украинскому языку и создает возможности для формирования лексической компетентности на основе электронной лингводидактики.

Ключевые слова: лексическая компетентность; учебно-компьютерная игра; электронная лингводидактика; интерактивный учебно-игровой комплекс.

\title{
FORMATION OF PUPILS' LEXICAL COMPETENCE BY COMPUTER GAMES IN THE STUDY OF UKRAINIAN LANGUAGE
}

\author{
Oksana A. Kucheruk \\ Doctor of Pedagogical Sciences, PhD, professor, \\ Department of world literature and methods of teaching philological disciplines \\ Zhytomyr State University name Ivan Franco, Zhytomyr, Ukraine \\ ORCID 0000-0002-7040-986X \\ okucheruk1@ukr.net
}

\begin{abstract}
The article deals with the problem of forming the lexical competence of younger teenage pupils with the use of computer games in the process of learning the Ukrainian language, the ways of its solution and the corresponding methodical recommendations are offered. The importance of creating and using computer games in order to improve the quality level of Ukrainian-language education is substantiated. The essence of the concepts of «lexical competence», «educational computer game» is specified. On the basis of analysis of scientific works, synthesis of educational and methodological ideas, generalization of own experience of pedagogical work the conditions of effective use of educational computer games within the limits of Ukrainian-language education are determined. It has been established that the integration of computer games into the traditional Ukrainian language learning system helps to provide internal motivation for learning, activating pupils 'cognitive activity, forming general and substantive competencies. It is emphasized that the effectiveness of educational computer games in the language training of students depends on the level of professional education, ICT competence and linguodidactic skill of a teacher-translator. The educational potential of an interactive educational game complex is described, which is to stimulate interest in teaching the Ukrainian language and creates opportunities for the formation of lexical competence on the basis of electronic linguodidactics.
\end{abstract}

Keywords: lexical competence; educational computer game; electronic linguodidactics; interactive educational-game complex.

\section{REFERENCES (TRANSLATED AND TRANSLITERATED)}

[1] H. Korytska, «School Language Education in the Development of the Electronic Learning Environment», E-learning in the theory and practice of teaching social and humanitarian disciplines: kolektyvna monohrafiia, zazah. red. H. R. Korytskoi, T. M. Putii, Ivano-Frankivsk, Ukraina: Symfoniia forte, s. 4054, 2017. (in Ukrainian) 
[2] V. Novosolova, «Methods, methods and means of teaching in the process of formation of lexical competence of students 5-7 grades», Ukrainian language and literature at school, №3 (113), s. 19-23, 2014. (in Ukrainian)

[3] Velasco Daniel García. «Lexical competence and functional discourse grammar», Brazil: Alfa, São Paulo, 51 (2): s.165-187, 2007.[online].

Available: http://piwik.seer.fclar.unesp.br/alfa/article/viewFile/1442/1150 (in Brazilian)

[4] Dzhon Raven, «Pedagogical testing: Problems, delusions, perspectives», Moskva, Rossyia: KohytoTsentr, 2001. (in Russian)

[5] L. V. Meleshko, «Interactive educational game complex. Ukrainian language in games (grades 5-6)». [online].Available: https://drive.google.com/open?id=1xt2ZLmseqBubhc44gRemRTBazsJZBFHg. Accessed on: Dec. 16, 2017. (in Ukrainian)

\section{(cc) BY-NC-SA}

This work is licensed under Creative Commons Attribution-NonCommercial-ShareAlike 4.0 International License. 